\title{
MEASURING THE DISTANCE: POLITICS AND COMMUNITY IN RAYMOND WILLIAMS' BORDER COUNTRY (1960) ${ }^{1}$
}

\author{
Roberto del Valle Alcalá, Universidad Autónoma de Madrid \\ Email: roberto.delvalle@uam.es
}

\begin{abstract}
The publication of Border Country in 1960 marks the expressive culmination of the theoretico-political project of the early Raymond Williams, as it is articulated in his seminal works Culture and Society and The Long Revolution. This semi-autobiographical novel presents a socio-historical horizon of contrasts and limits or "borders" (between a metropolitan modernity and a rural "margin" openly marked by class circumstances) organised around the concept of community. Through Matthew Price's spatio-temporal (but also emotional and political) journey to his native village of Glynmawr, in the border region between Wales and England, Williams analyses historical fractures and ideological distances whilst simultaneously exploring the emancipatory potentialities of a decidedly collective and "ordinary" social experience.
\end{abstract}

Keywords: Community; border; Wales; culture; class

Título en español: Midiendo la distancia: Política y comunidad en Border County (1960) de Raymond Williams

Resumen: La publicación de Border Country en 1960 constituye la culminación expresiva del proyecto teórico-político del primer Raymond Williams, tal y como queda definido en sus dos trabajos críticos seminales, Culture and Society y The Long Revolution. Esta novela semi-autobiográfica presenta un horizonte histórico y social de contrastes y límites o "fronteras" (entre una modernidad metropolitana y un "margen" rural abiertamente marcado por las circunstancias de clase) articulado en torno al concepto de comunidad. A través del viaje (espacio-temporal, pero también emocional y político) de Matthew Price a su pueblo de origen en la región fronteriza entre Gales e Inglaterra, Williams analiza fracturas históricas y distancias ideológicas al tiempo que explora las potencialidades emancipatorias de una experiencia de lo social marcadamente colectiva y "ordinaria". Palabras Clave: Comunidad; Frontera; Gales; cultura; clase

Raymond Williams' critical project in the late 1950s and early 60s, as defined in his seminal works Culture and Society and The Long Revolution, can be described as a radical examination of "common" possibilities and alternatives to the "bourgeois idea of society" understood as a projective space of the atomising tendencies inscribed in industrial capitalism and its attendant forms and ideologies of social organisation. Williams' programmatic articulation of a counter-hegemonic model of "common culture" (Williams 1961: 285-324)

Date of reception: 24 May 2010

Date of acceptance: 20 September 2010

Odisea, $n^{\circ} 11$, ISSN 1578-3820, 2010, 7-16 
as a general political horizon of radical social change ultimately stems from a native experience and formula of culture as a specific set of "ordinary" meanings and processes (Williams 1993: 89-102). Nowhere is the thematic and political unity of this initial formulation of democratic praxis in Williams' oeuvre given a more open or straightforward inflection than in his first published work of fiction, the semi-autobiographical novel Border Country.

Border Country marks an initial exploration of Williams' personal trajectory as well as a crucial mediation of the overarching intellectual concerns addressed in Culture and Society and The Long Revolution. As Stephen Woodhams has noted, "Border Country had begun to be written in 1946 as Brynllwyd, and represents the most immediate means by which Williams pursued his own passage through these years" (Woodhams 2001: 98). ${ }^{2}$ It seems that the conceptual profile of the reflection, articulated through the personal trinity of "culture", "community" and "Wales" ("in which "Wales' serves to frame the other two", according to Dai Smith (Smith 1993: 279), required a strategic move beyond the resilient academicism of the critical essay, and that only the signifying fluidity of the novel form could capture and engage with the experiential complexities of a lived culture in common.

Border Country is a vital instance of reflective self-interrogation -a critical scrutiny of the general historical moment which frames his initial incursion into the field of cultural theory (the "affluent" 1950s), and a penetrating account of the complex negotiation of personal and general loyalties which directly concerned Williams' generation of "scholarship boys". The narrative of upward mobility which provides the background to the novel and to Williams' own trajectory is permanently destabilised, mediated and significantly reconfigured by the prominence of a fundamental notion -that of the border- which informs both the title of the novel and the bulk of Williams' historical understanding of the term "culture".

The border to which the novel alludes is, in that sense, the ontological condition inhabited by Williams himself and by his fictional alter ego, Matthew Price. It provides the spatial context of a personal dislocation (from rural Wales to metropolitan London); ${ }^{3}$ it entails the social dimension of a cross-class transition (from working- to middle-class); it involves a temporal margin or historical separation between the heroic moment of the 1926 General Strike and the "meretricious society" of the Fifties. And most importantly, it balances the permanently unresolved in-betweenness of his moral world (Welsh and English, workingand middle-class, collectivist and individualist).

\footnotetext{
2 Williams produced some seven successive versions of the novel between 1947 and 1960, as he strove to develop a form which would precisely express the sort of transformation in which his personal and social experience was involved. Thus, he sought to disengage it from the available models, which tended to confine the individual and collective dimensions to an enclosed, or cut-off, "zone of experience": "The early versions of Border Country were continuous with these kinds of writing... Then I gradually realized that with the degree of change after 1945 the problem was to find a fictional form that would allow the description both of the internally-seen working-class community and of a movement of people, still feeling their family and political connections, out of it" (Williams, 1979: 272)

3 In The Country and the City, Williams relates this primary sense of dislocation to a general twentieth-century doxa about the fading of the "rural experience, [of] the working country", and comments on the effects this had on his own thinking: "I accepted this, at one level, for much longer than now seems possible...And I cannot clearly remember when I suddenly realised that it was not really true at all.” (Williams, 1993: 299)
}

Odisea, $n^{\circ} 11$, ISSN 1578-3820, 2010, 7-16 
Border Country is an account of intellectual and material exile from a firm sense of primary, original attachment -from the Lawrentian world of "close, quick relationships" (Williams 1961: 205)- and a quest for common meanings and values. It is, in other words, a reawakening to "identity" through a renovated experience of community.

Matthew Price's return to the native community, to the Welsh border village of Glynmawr, as his father falls terminally ill, paves the way for an emotional pilgrimage back to the common sources of selfhood and belonging, revealing, in the process, a complex set of relations and alliances. An economic historian by training, Price's research deals with "population movements into the Welsh mining valleys in the middle decades of the nineteenth century" (Williams 2006: 4). His own lived experience of a similar movement confronts him with the limitations of measurement, of the means and techniques of measurement required by the scientific approach of his particular discipline and the basically inaccessible -ungraspable, unfixable- essence of the measured object:

The techniques I have learned have the solidity and precision of ice-cubes, while a given temperature is maintained. But it is a temperature I can't really maintain; the door of the box keeps flying open. It's hardly a population movement from Glynmawr to London, but it's a change of substance, as it must also have been for them, when they left their villages. And the ways of measuring this are not only outside my discipline. They are somewhere else altogether, that I can feel but not handle, touch but not grasp. (Williams 2006: 4)

Only the immanent trajectory of a psychological journey back to the native milieu, only an internal reconstruction of the experience of displacement, loss and recovery, can successfully bridge this change of substance. Only, as the novel sets out to exemplify, the holistic interpretation of culture as an integral way of life (as "a whole way of life"), as a total embodiment of meaningful relations and their derivative set of values, can express the vital dimension of social inquiry, while external, forensic, observation only grasps at the surface.

The journey home is a relapse into the rhythms of a foregone past - "Abruptly the rhythm changed, as the wheels crossed the bridge" (Williams 2006: 8) -, into the realm of an old habitation colliding with the circumstances of personal dislocation. The crossing of the border, signalled in the narration by a change of rhythm which is reflected in the syntax as a shift to longer, parsimonious, sentences, marks the resurrection of an experiential kernel punctuated by distance, nostalgia and, increasingly, the proper combinations of an enabling recognition. ${ }^{4}$ Along with the peculiar rattle of the carriage, as the Herefordshire borderlands fade into the Welsh landscape, the temporally removed awareness of belonging is shaped into a present concern, into an immediate compulsion to re-live forgotten connections and repressed ways. This becomes apparent as soon as Matthew sets foot in the local station at Gwenton and, self-engrossed in reverie, fails to recognise the voice of an old family friend, Morgan Rosser, who has come to pick him up:

\footnotetext{
See di Michele (1993)
} 
As he walked down the station approach, a car drove towards him, raking him with its headlights, in which the rain drifted. The driver blew his horn, but Matthew ignored it. He walked on, steadily, turning his face from the wind. So much of his memory of this country was a memory of walking: walking alone, with the wind ripping at him; alone it seemed always, in memory, though not in fact. (Williams 2006: 9-10)

In trying to reconstruct this elemental, distant sensation -the core images of his native life- Matthew seems to forget or exclude the determining factor in that ungraspable "substance" which his scientific method cannot properly isolate: the lived experience of community, which was characterised, as Williams had reportedly known it in childhood and adolescence, by "the extending obligations of neighbourhood". (Williams 1989a: 115)

Williams' definition of the "country" is fleshed out in this distinctive quality of the minimal bond and the loaded interpersonal space. Matthew's encounter with Morgan Rosser prompts the re-absorption of his present, alien self (urban, middle-class, intellectual) into the old textures and patterns of behaviour - it compels, without the intervention of external measurement, a deep, unverbalised understanding of life in common: "It is like this, this country; it takes you over as soon as you set foot in it." (Williams 2006: 11)

The encounter with the bed-ridden father makes this resurgent awareness all the more pressing and urgent. Now the formal, contrived, veil upon which much of his acquired, contemporary identity depends is revealed useless in this extraordinary effort to communicate with the past. Matthew gives way to Will, the name under which he had been known throughout childhood, and words, for the most part, give way to postures, to gestures and generally, to the physical immediacy of emphatic silence and muted yet meaningful dialogue:

$[\mathrm{H}]$ is whole mind seemed a long dialogue with his father - a dialogue of anxiety and allegiance, of deep separation and deep love. Nothing could stop this dialogue, nothing else seemed important, yet here, with the pale hand lying by his own hand, with the face no longer an image but there, anxiously watched, the command to silence was absolute, while the dialogue raced. (Williams 2006: 20)

The relative distance of personal circumstance and temporal ascription (the fact that Matthew belongs in the 1950s whilst Harry comes across as more of a figuration of a bygone world) is bridged by this elemental community of sensation between dying father and returning son. The loaded temporality of imminence (the tense expectancy of the coming end, of Harry's death) is overlaid in this passage with an intensity of identification which lays, in a way, the emotional foundations of subsequent instances of community in the novel.

The family (interestingly emblematised by the father-son relationship, while the role assigned to the mother is considerably less prominent) supplies a preliminary context for communality - a primordial scenario of shared meanings and obligations which prefigures, and yet is only validated or sanctioned by, its extension into the larger social grouping. Thus, for example, the psychologically distant portrait of the paternal grandfather, hanging on the bedroom wall, manages to convey a secret intimation of a primary bond which only becomes meaningful as part of a larger, social, experience: 
Here again was complexity. The mediocre photograph had the life of a fine portrait... Jack Price, labourer, very formal in the stiff, high collar and the smooth, unworn lapels and waistcoat. Then the eyes, colourless in the hazy enlargement, but not his son's eyes, clouded, unfocused; eyes still with the devil in them, the spurt of feeling and gaiety. Remembering their living excitement, Matthew stared back feeling their world. (Williams 2006: 21)

It is the intimation of a whole way of life made available in the visual trajectory - the longing eye meeting the full expression of a past life-world. The weight of the silent dialogue is sustained by the look and the deep understanding of a process which is unexceptional, yet complex, ongoing and thoroughly social.

Matthew Price's journey home is an attempt to unravel the inner significance of this life-world as it has grown removed and foreign from personal experience. And it is fundamentally an attempt to reconnect its outward aspects (its crystallisation in memory and detached analysis as a familiar image, a landscape etc) to the dense, inner life of a living world. The bid to resuscitate the old codes of interaction (the "intrusive" neighbours, the closeness and mutuality of social life) combines with the effort to galvanise old graphic detail (the valley and the mountains of childhood) back into a real, effective presence. Work, that is, the realisation of work as the primary social relationship whereby individual human lives are brought together into a functioning whole, marks the transition to this galvanic activation. It operates as the organising framework (the social context) within which the reconnection can be achieved:

He had felt empty and tired, but the familiar shape of the valley and the mountains held and replaced him. It was one thing to carry its image in his mind, and he did, everywhere, never a day passing but he closed his eyes and saw it again, his only landscape. But it was different to stand and look at the reality. It was not less beautiful; every detail of the land came up with its old excitement. But it was not still, as the image had been. It was no longer a landscape or a view, but a valley that people were using. He realized, as he watched, what had happened in going away. The valley as landscape had been taken, but its work forgotten. The visitor sees beauty; the inhabitant a place where he works and has his friends... This was not anybody's valley to make into a landscape. Work had changed and was still changing it, though the main shape held. (Williams 2006: 91)

The colour of social interaction - the interpersonal rhythms of the border country - is in itself a constant reminder, for Matthew's exilic consciousness, of that "network" in which native life had been steeped in the beginning. ${ }^{5}$ The emotional reawakening of "Will", by

\footnotetext{
5 According to the critical terms set down by Williams himself, Border Country qualifies in this particular respect as a "true industrial novel": "Both the realist and the naturalist novel, more generally, had been predicated on the distinctive assumption... that the lives of individuals, however intensely and personally realized, are not just influenced but in certain crucial ways formed by general social relations. Thus industrial work, and its characteristic places and communities, are not just a new background: a new 'setting' for a story. In the true industrial novel they are seen as formative. Social relations are not assumed, are not static, are not conventions within which the tale of a marriage or an inheritance or an adventure can go its own way. The working society actual work, actual relations, an actual and visibly altered place - is in the industrial novel central: not because, or not necessarily because, the writer is 'more interested in sociology than in people' ... but because in these
} 
the father's deathbed, is inextricably bound up with a reawakening, from the torpid social and political standpoint of 1950s metropolitan Britain, to the collective energies of, first, an old country mode and, second, a foregone conjuncture of politically conscious "common life".

The novel rehearses History as both the general horizon and the natural extension of conflicts, negotiations and victories achieved at the level of small-scale interpersonal alliances. The drama of the 1926 General Strike provides the concrete framework in which these patterns are tested and the specific formulations of community and culture (of the whole way of life), fleshed out. With the novel's time frame shifting to 1926 and the crucial events of that year, the circumstances of unprecedented co-ordinated class action serve a particular purpose of collective self-definition and identification. The strike is accorded pride of place in the general organisation and ulterior contextualisation of social and individual identities: the bonds and fractures generated by this single but momentous action constitute the historical and biographical foundation upon which subsequent instances of community and communication (between Matthew and his father, between Matthew and Morgan Rosser, between Rosser and Harry etc) will - implicitly, for the most part - be measured. ${ }^{6}$

Thus the idiosyncratic forms of labour and militancy enacted on the structural (and geographical) outskirts of industrial life (whose "centre" would be represented by the mining valleys to the south-west) constitute a symptomatic development of the idea and the practice of community. The experience of the Strike in Glynmawr is mediated by its marginal position in the Black Mountains, and its "border" location between England and Wales, between an old, backward rurality and the foward-looking world of industrialisation. Analogously, Harry Price and Morgan Rosser's active participation in the Strike is marked by yet another border position within their class affiliation: as signalmen working at the local railway station their identification with the cause of the miners is both external and yet central; it is dialecticised as a formative dynamic of their own social relations in and personal experience of the local community. As Williams noted in a later piece:

[B]y the very fact of the railway, with the trains passing through, from the cities, from the factories, from the ports, from the collieries, and by the fact of the telephone and the telegraph, which was especially important for the signalmen, who through it had a community with other signalmen over a wide social network, talking beyond their work with men they might never actually meet but whom they knew very well through voice and opinion and story, they were part of a modern industrial working class. (Williams 1989b: 106)

The striking railwaymen, through their particular experience of commitment, solidarity, internal defection and eventual defeat, manage to isolate the dynamic and formative nature of social relations as a dialectical structure with general, external conditions in the public

working communities it is a trivial fantasy to suppose that these general and pressing conditions are for long or even at all separable from the immediate and the personal." (Williams 2005: 221-222)

6 As Dai Smith has noted, in its published version, the novel differs in its emphasis on the Strike from the draft version Border Village, where "the issues and incidents are brought together, before the General Strike, to show how 'the common good' can be attained by working together. We see a community taking on deeper formations before the Strike rather than merely as one of its consequences" (Smith 2008: 431)

Odisea, $n^{\circ} 11$, ISSN 1578-3820, 2010, 7-16 
realm and local, particular developments in the personal sphere. A specific discipline of loyalty to their fellow workers, to their union and to their class is exercised in what constitutes the novel's political and emotional core. From the general "principle" of class solidarity which causes the action - as Harry puts it to Major Blakely "Part of the fair price for any man is a fair price for his brother. I wouldn't want it if the miners went without" (Williams 2006: 142) - to the final, validating consequence derived by the striking men (a concrete experience of "actual" solidarity), a routine of rural, border-country, common life has been strengthened and a new prospect of mutual endeavour has risen from the known textures of common experience: "[t]hey seemed to know instinctively that it was important to be with each other." (Williams 2006: 156)

The bitter realities of defeat, betrayal (by the union and the TUC) and victimisation in the wake of the strike contribute a further dimension to this complex arrangement. The most characteristic transformation concerning the social corollary of this experience is perhaps that which affects Morgan Rosser:

The end of the strike had changed Morgan. Harry had lost most, by being off work, but recovered quickly... But for Morgan, really, there was no satisfaction. A struggle had been lost; a common effort had failed. And it was not only the failure that broke him, but the insight this gave, or seemed to give, into the real nature of society. His life had been centred on an idea of common improvement. The strike had raised this to an extraordinary practical vividness. Then, suddenly, a different reality had closed in. (Williams 2006: 189)

The imperative confirmation of compromise over commitment, as rehearsed in the traumatic form of a major historical disappointment (a calculated betrayal - in the bitter reckoning of the more militant elements of the labour movement - of conceivable, radical, social change), is rationalised through the reorientation of personal purpose. Morgan becomes a vehicle for the essentially dramatic subsumption of a whole world (a whole "structure of feeling", in a phrase Williams would popularise) within its embodied negation: feelings of political solidarity and collective effort give way to the individual ambitions of small-scale entrepreneurship.

But despite the apparent failure of the common project outlined and heralded by the strike, the nature and scope of the living sociality addressed by the novel lies deeper, in a structure of interpersonal feeling and action which surfaces under external contrast and which underpins the general rationale behind Matthew's adult re-encounter with the community through a "private" re-encounter with the dying father. This deeper structure is captured in the novel by one of those external observers - the vicar, Arthur Pugh - who, early on in Matthew's life, supplies him with a key to the general understanding he will only attain many years later. The actual profile of a "common life" is distinguished beyond the external appearances of customary interaction, in a logic of mutual dependency and undivided existence which underpins every other aspect of observable social life. As Pugh puts it:

'The real life here, Matthew, is the growing and the selling. At least it often seems so, seems no more. But that isn't fair. The real life, for these people, is each other. Even their religion is for each other... The chapels are for people to meet, and to talk to each other or sing together. Around them, as you know, moves almost the whole life of the 
village. That, really, is their religion... The chapels are social organizations, Matthew. The church here is not. I don't mean that their religious professions are insincere, but they could equally, it seems to me, be professions in almost anything - any other system of belief, for instance. What matters, what holds them together, is what their members do, through them, for each other. God, you might say, is their formula for being neighbourly.' (Williams 2006: 278)

The traditions of Welsh Nonconformity are singled out as the native locus of an organisation of feelings and loyalties through which community - qua real, lived experience of moral togetherness - is forged in this context. ${ }^{7}$ And neighbourliness, perhaps the semantic crux of emotional alliances in this novel, is given as the interpersonal formula on which an entire social ontology, as it were, is predicated. ${ }^{8}$

Matthew Price's removal from this universe of physical and moral continuities involves the traumatic blurring of a native ethic and a vital space in which identity still preserves the organic meaning of an actual way of life. The realisation of psychological distance and personal exile gives the measure of loss, through which ultimate recovery is rendered possible. Thus the climax of the novel is to some extent epiphanical, as the interrupted journey back to London (due to Harry's second and fatal stroke) presents the adult son with the open profile of his predicament and, paradoxically, with the enabling condition of his successful homecoming. While waiting on the platform for the outbound train, the communal principle of this forgotten life becomes apparent:

The long platform was crowded, and he moved into one of the few empty spaces. Then he caught what he was doing, and hesitated. It had become a habit, this moving away, a habit no less his own because it was also the habit of his crowded society. The immediate defence prepared itself; that he was country-bred, used to space and aloneness. And this defence was plausible, the need to be alone was real, until the crowded hall, the chapel, the bus, were remembered. He saw how over the years he had been steadily moving away, avoiding contact. The way of thinking which had supported him in this seemed suddenly a dead weight, an immaturity of which he had been conscious since this crisis in his father's life... Closing his eyes, he saw Harry's heavy body, and the crowd moved in it, the crowd in its constant pressure. (Williams 2006: 392-393)

\footnotetext{
7 As Robert Pope notes, "Nonconformist ecclesiology [was] characterized by a classless gwerin, 'a country's residents of every grade and class'. The word 'gwerin' reflected at best a prohibitive social moralism, one that required its adherents to recognize the fundamental equality of all men under God, and at worst a philosophy of denial." (Pope 1998: 4)

8 Williams would later dwell on the established as opposed to the experiential uses of the term "neighbour". In a famous passage, he recalls a characteristic clash with Professor L.C. Knights at Cambridge: "He said that the word 'neighbour' in Shakespeare indicated something that no twentieth-century person can understand, because it signified a whole series of obligations and recognitions over and above the mere fact of physical proximity... Well, then I got up, straight from Pandy, so to say, and said I knew perfectly well what 'neighbour', in that full sense, means... Now this was not to idealize my own place...I do not mean that people all liked each other. I do not mean that people didn't play dirty tricks on each other sometimes. I do not mean that people didn't have disputes. I mean that there was nevertheless a level of social obligation which was conferred by the fact of seeming to live in the same place and in that sense to have a common identity. And from this sense there were acts of kindness beyond calculation, forms of mutual recognition even when they were wild misrepresentations of the world outside." (Williams 1989a: 113-114)
}

Odisea, $n^{\circ} 11$, ISSN 1578-3820, 2010, 7-16 
The completion of the journey awaits in this climactic realisation, and in the unspoken knowledge of a deep continuity across differences of circumstance, emphasis and manner. The distance presupposes change, evolution and separation, but it also dictates - in the final reckoning - a complex and substantive arrangement whose acceptance alone can end exile and grant the sort of understanding from which external, scientific analysis is excluded: "Not going back, but the feeling of exile ending. For the distance is measured, and that is what matters. By measuring the distance, we come home." (Williams 2006: 436). ${ }^{9}$

Williams' work is singularly immersed in this peculiar "ethic" of measurement. Some of the critical aspects outlined in his early interventions on the theory of culture were thus to be recombined in a multi-form yet co-ordinated effort whose projected political consequences were, as we have seen, often inseparable from the most personal and reflective formulations.

\section{REFERENCES}

Di Michele, L. 1993. "Autobiography and the "Structure of Feeling" in Border Country." Views Beyond the Border Country: Raymond Williams and Cultural Politics. Eds. D. L. Dworking and L.G. Roman. New York/ London: Routledge.

Pope, R. 1998. Building Jerusalem: Nonconformity, Labour and the Social Question in Wales, 1906-1939. Cardiff: University of Wales Press.

Sмiтh, D. 1993. Aneurin Bevan and the World of South Wales. Cardiff: University of Wales Press.

Smith, D. 2008. Raymond Williams: A Warrior's Tale. Cardigan: Parthian.

Williams, R. 1961 [1958]. Culture and Society 1780-1950. Harmondsworth: Penguin.

Williams, R. 1965 [1961]. The Long Revolution. Harmondsworth: Penguin.

Williams, R. 1979. Politics and Letters. London: New Left Books.

Williams, R. 1989a [1977]. "The Importance of Community". Resources of Hope: Culture, Democracy, Socialism. Ed. Robin Gable. London: Verso.

Williams, R. 1989b [1977]. "The Social Significance of 1926". Resources of Hope: Culture, Democracy, Socialism. Ed. Robin Gable. London: Verso.

Williams, R. 1993 [1958]. "Culture is Ordinary”. Border Country: Raymond Williams in Adult Education. Eds. J. McIlroy and S. Westwood. London: NIACE.

Williams, R. 1993 [1973]. The Country and the City. London: The Hogarth Press.

\footnotetext{
9 This peculiar understanding of the emotional exile in Border Country has been likened to Williams' own treatment of Lawrence. As Laura di Michele has observed "Perhaps Williams thought of him [Matthew] in terms very similar to those he used to discuss Lawrence's type of exile: it was a necessary exile to gain the necessary distance and consciousness of oneself and of the other members of the community, to acquire the necessary sensibility to feel and understand the close relationships which connect the people of an 'organic' community together." (Di Michele 1993: 28)
} 
Williams, R. 2005 [1980]. Culture and Materialism. London: Verso.

Williams, R. 2006 [1960]. Border Country. Cardigan: Parthian.

Woodhams, S. 2001. History in the Making: Raymond Williams, Edward Thompson and Radical Intellectuals 1936-1956. London: Merlin Press. 